Article

\title{
Experimental Study of Condensation Heat Transfer and Pressure Drop inside a Small Diameter Microfin and Smooth Tube at Low Mass Flux Condition
}

\author{
M. Khairul Bashar ${ }^{1}$, Keisuke Nakamura ${ }^{1}$, Keishi Kariya ${ }^{2}{ }^{\circledR}$ and Akio Miyara ${ }^{2,3, *}$ \\ 1 Graduate School of Science and Engineering, Saga University, 1 Honjomachi, Saga 840-8502, Japan; \\ khairul.me08@gmail.com (M.K.B.); 18575024@edu.cc.saga-u.ac.jp (K.N.) \\ 2 Department of Mechanical Engineering, Saga University, 1 Honjomachi, Saga 840-8502, Japan; \\ kariya@me.saga-u.ac.jp \\ 3 International Institute for Carbon-Neutral Energy Research, Kyushu University, Fukuoka 819-0395, Japan \\ * Correspondence: miyara@me.saga-u.ac.jp; Tel.: +81-952-28-8623
}

Received: 22 October 2018; Accepted: 31 October 2018; Published: 2 November 2018

\begin{abstract}
This study was made to investigate the condensation local heat transfer and adiabatic pressure drop of R134a inside a $2.5 \mathrm{~mm}$ outside diameter smooth and microfin tube at low mass flux condition. Data were measured for mass fluxes from 50 to $300 \mathrm{~kg} \mathrm{~m}^{-2} \mathrm{~s}^{-1}$, vapor qualities from 0 to 1 and saturation temperatures from 20 to $30^{\circ} \mathrm{C}$. The effects of mass flux, vapor quality, saturation temperature, microfin and diameter of test tube were analyzed. The pressure drop of the microfin tube was about 1.5 times higher than that of the smooth tube at mass flux $50 \mathrm{~kg} \mathrm{~m}^{-2} \mathrm{~s}^{-1}$. The heat transfer coefficient of the microfin tube was about 2-5 times higher than that of the smooth tube at mass flux $100 \mathrm{~kg} \mathrm{~m}^{-2} \mathrm{~s}^{-1}$. Experimental results were also compared with typical correlations. For the microfin tube, however, all the existing correlations do not adequately predict the present data. Poor predictions may be attributed to the lack of the small diameter microfin tube with low mass flux data in their database. Hence, it is essential to develop a condensation and pressure drop correlation for the small diameter microfin tube at low mass flux condition.
\end{abstract}

Keywords: microfin tube; condensation; heat transfer coefficient; pressure drop; R134a

\section{Introduction}

The demand for air-conditioner and refrigerator is increasing in both developed and emerging countries along with the development of life standard. Therefore, the energy demand of the world is increasing and expected to be higher in the near future; however, already because of using a huge amount of energy, the earth's climate has changed. Manufacturers are now using the environment friendly latest technology advancement in the air-conditioning and refrigeration field to improve the system performance. Recently, small diameter $\left(d_{0}<7 \mathrm{~mm}\right)$ microfin and smooth tube use in RAC industry can improve the system performance. Moreover, small diameter microfin tubes also provide many other advantages such as reduction of refrigerant charge, less weight, effectiveness, compactness, environment friendly, etc. In microfin tubes, as they consist of fins, the effects of surface tension and shear stress on the heat transfer regime are also changed, which causes the heat transfer coefficients and pressure drops in small diameter microfin tubes to perform differently from those in conventional smooth tubes. Additionally, to keep the pressure drop minimum of small diameter tubes, low mass flux operation of the refrigerant is necessary. Thus, there is a need to investigate the condensation heat transfer and adiabatic pressure drop inside the small diameter tube at low mass flux condition.

Some studies have been done to analyze the condensation heat transfer and pressure drop characteristics of refrigerants inside small diameter microfin tubes, for example, tubes with outer 
diameters of $7.52 \mathrm{~mm}$ [1], $7.0 \mathrm{~mm}[2,3], 6.0 \mathrm{~mm}$ [4], $5.0 \mathrm{~mm}$ [5], $4.0 \mathrm{~mm}[6,7], 3.5 \mathrm{~mm}$ [8] and $3.0 \mathrm{~mm}$ [9]. In recent years, some researchers who have analyzed different aspects related to condensation inside smooth and microfin tubes are Zhuang et al. [10], Fronk and Garimella [11], Dorao and Fernandino [12], Xiao and Hrnjak [13], Ghim and Lee [14], Meyer and Ewim [15] and Shah [16]. However, some investigations on the condensation heat transfer characteristics and frictional pressure drop in microfin and smooth tube are not in good agreement. Therefore, it is necessary to carry out more experiments in microfin tubes. In this study, the condensation heat transfer and frictional pressure drop characteristics of R134a in small diameter smooth and microfin tube were investigated and the experimental data compared with some related studies.

\section{Experimental Apparatus and Procedure}

A detailed schematic diagram of the experimental apparatus including its different components is presented in Figure 1. The experimental apparatus comprises of a Coriolis mass flow meter, three mixing chambers, two pre-heaters, test sections, a cooler, an accumulator, cooling/heating water loop and data logger. The liquid refrigerant is kept in the refrigerant tank. Then, the refrigerant is pumped by a gear pump. After that, it flows through the filter, mixing chamber, pre-heaters, sight glass, test section, cooler and accumulator. To continue the cycle, the refrigerant is again circulated from the cooler after being collected in an accumulator and returned to the pump. However, to get the desire vapor quality in the test section inlet, the refrigerant quality is controlled and superheated by the first and second preheaters, respectively. The heated/superheated refrigerant passes into the test section and experimental data are obtained in the different vapor quality ranges. To exchange the heat between refrigerant and water, the test section consists of a tube-in-tube heat exchanger. After exchanging heat, refrigerant leaves the test section, flows through the cooler, and is completely subcooled by brine. Brine is reserved at a fixed temperature in the heat source unit. The accumulator is used to control the system pressure of the experimental apparatus. The Coriolis mass flow meter measures the mass flow of refrigerant. Three mixing chambers are fitted in the different locations to measure the bulk temperature of the refrigerant. Two sight glasses at the inlet and outlet of the test section are fitted to observe the refrigerant's quality. The absolute pressure transducer is fitted to measure the pressure of refrigerant. K-type and T-type thermocouples are fitted at different locations to measure the temperature of refrigerant and tube wall, respectively. All signals from the measuring devices are collected by a data logger. Moreover, the total experimental apparatus is well insulated so it is not affected by outside temperature.

Figure 2 shows details of the test section, which consists of a horizontally installed copper tube, two headers, three water channels and three sub-sections. The total test section length is $852 \mathrm{~mm}$, each sub-section length is $248 \mathrm{~mm}$ and effective cooling/heating length is $744 \mathrm{~mm}$. The refrigerant flows inside the test tube, while the counter-current water flows through the water loop, as shown in Figure 2. A differential pressure transducer is fitted in the test section header to measure the pressure difference. Thermocouples are inserted at various locations to measure the temperature (Figure 2). Devices such as thermocouple calibration were measured over the applicable range. The K-type and T-type thermocouples measurement uncertainty was estimated as $\pm 0.03^{\circ} \mathrm{K}$. The absolute and differential pressure transducer measurement uncertainty was estimated as $\pm 0.1 \mathrm{KPa}$. The Coriolis mass flow meter measurement uncertainty was estimated as $\pm 0.15 \%$.

The test tube is made of copper. Two types (smooth and microfin) of test tube were used in this study and both tubes have outside diameters of $2.5 \mathrm{~mm}$, as shown in Figure 3. The tube dimensions are listed in Table 1. Refrigerant mass flux varied from 50 to $300 \mathrm{~kg} \mathrm{~m}^{-2} \mathrm{~s}^{-1}$ and the saturation temperature varied from 20 to $30^{\circ} \mathrm{C}$. The usual refrigerant thermophysical properties of R134a used in the experiment are shown in Table 2. 


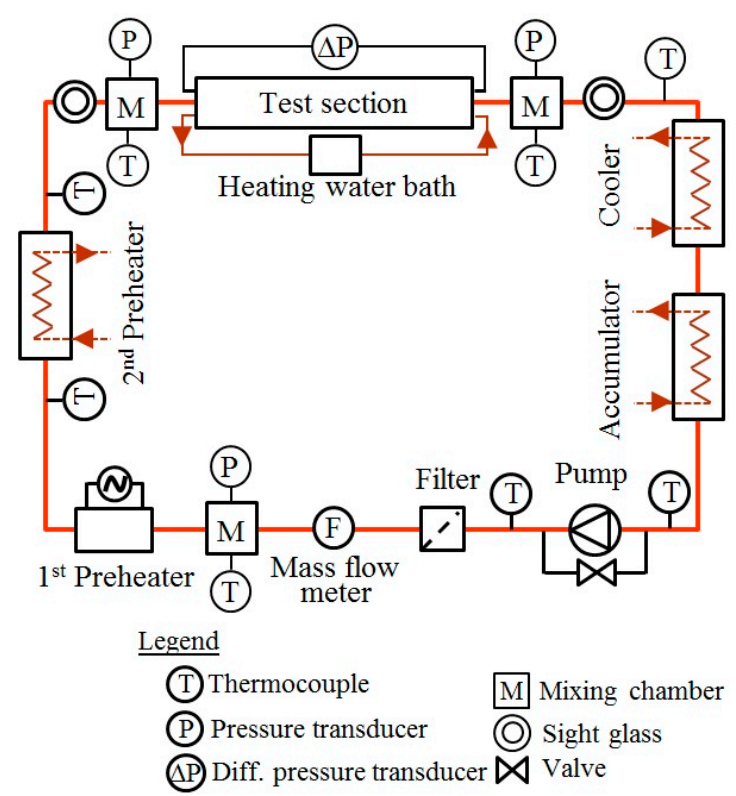

Figure 1. Schematic diagram of the experimental apparatus.

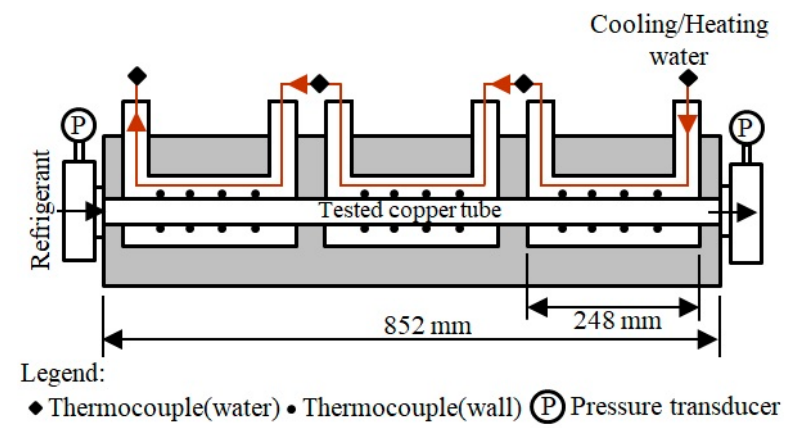

Figure 2. Details of the test section.

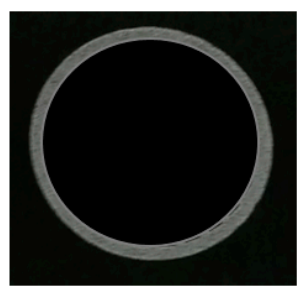

(a)

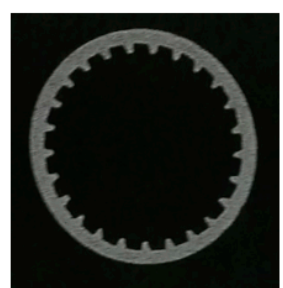

(b)

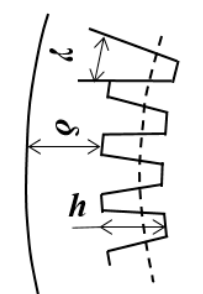

(c)

Figure 3. Photography and schematic view of the test tube: (a) smooth tube; (b) microfin tube; and (c) schematic view of the microfin tube.

Table 1. Specifications of the test tubes.

\begin{tabular}{ccc}
\hline Parameter [Unit] & Smooth Tube & Microfin Tube \\
\hline Outside diameter $d_{o}[\mathrm{~mm}]$ & 2.5 & 2.5 \\
Inner diameter $d_{i}[\mathrm{~mm}]$ & 2.14 & - \\
Equivalent diameter $d_{e}[\mathrm{~mm}]$ & - & 2.17 \\
Wall thickness $\delta[\mathrm{mm}]$ & 0.18 & 0.15 \\
Fin height $h[\mathrm{~mm}]$ & - & 0.10 \\
Apex angle $\gamma\left[^{\circ}\right]$ & - & 31 \\
Helix angle $\theta\left[^{\circ}\right]$ & - & 10 \\
Number of fin $n[-]$ & - & 25 \\
\hline
\end{tabular}


Table 2. Thermophysical properties of R134a [17].

\begin{tabular}{cccccccc}
\hline $\begin{array}{c}\boldsymbol{T}_{\text {sat }} \\
{\left[{ }^{\circ} \mathbf{C}\right]}\end{array}$ & $\begin{array}{c}\rho_{l} \\
{\left[\mathbf{k g ~ m}^{-3}\right]}\end{array}$ & $\begin{array}{c}\rho_{v} \\
{\left[\mathbf{k g ~ m}^{-3}\right]}\end{array}$ & $\frac{\rho_{l}}{\rho_{v}}$ & $\begin{array}{c}\mu_{l} \\
{[\mu \mathbf{P a}-\mathbf{s}]}\end{array}$ & $\begin{array}{c}\mu_{v} \\
{[\mu \mathbf{P a}-\mathbf{s}]}\end{array}$ & $\frac{\mu_{l}}{\mu_{v}}$ & $\begin{array}{c}\sigma \\
{\left[\mathbf{m N ~ m}^{-\mathbf{1}}\right]}\end{array}$ \\
\hline 20 & 1225.90 & 27.65 & 44.34 & 207.75 & 11.48 & 18.09 & 8.71 \\
25 & 1207.30 & 32.20 & 37.50 & 195.25 & 11.68 & 16.71 & 8.05 \\
30 & 1188.00 & 37.37 & 31.79 & 183.47 & 11.90 & 15.41 & 7.40 \\
\hline
\end{tabular}

\section{Data Reduction}

The local condensation heat transfer coefficient, $\alpha$, is calculated by Equation (1).

$$
\alpha=\frac{Q_{c}}{\pi d_{e q} L\left(T_{R}-T_{w i}\right)}
$$

where $Q_{c}$ is the heat transfer amount of cooling water side, in each sub-section. $L$ is the effective heat transfer length of the test section, and $d_{e q}$ is the equivalent diameter of the test microfin tubes. When the smooth tube $d_{e q}$ was used in the experiment, it was defined by the inner diameter $d_{i}$. T $T_{R}$ is the refrigerant temperature and it was estimated from the measured refrigerant pressure. $T_{w i}$ is the inner wall temperature and it was calculated by the one-dimensional equation of heat conduction.

$$
T_{w i}=T_{w o}+Q_{c} \ln \left(\frac{d_{o}}{d_{e q}}\right) /\left(2 \pi \lambda_{c} L\right)
$$

where $T_{w o}$ is test tube outside wall surface temperature, $d_{0}$ is the outside diameter of the test tube, and $\lambda_{c}$ is the thermal conductivity of the copper test tube.

The total two-phase adiabatic pressure drop $\Delta P_{T}$ is expressed as the sum of frictional pressure drop $\Delta P_{F}$, pressure drop due to the abrupt contraction $\Delta P_{c}$ and expansion $\Delta P_{e}$ at the inlet and outlet of the test section, respectively.

$$
\Delta P_{T}=\Delta P_{F}+\Delta P_{C}+\Delta P_{e}
$$

The pressure drop because of the abrupt contraction and expansion were estimated by Equations (4) and (5), respectively, according to the Collier and Thome method [18].

$$
\begin{gathered}
\Delta P_{c}=\frac{G^{2} v_{l}}{2}\left[\left(\frac{1}{C_{c}}-1\right)^{2}+\left(1-\frac{1}{\beta^{2}}\right)\right]\left[1+\left(\frac{\Delta v_{v}}{v_{l}}\right) x_{a}\right] \\
\Delta P_{e}=G^{2} \beta(1-\beta) v_{l}\left[\frac{\left(1-x_{a}\right)^{2}}{(1-\xi)}+\left(\frac{v_{v}}{v_{l}}\right) \frac{x_{a}^{2}}{\xi}\right]
\end{gathered}
$$

where $\beta$ is area ratio and the coefficient of contraction $C_{c}$ is a function of $\beta$. The void function, $\xi$, is calculated by Smith's separated flow model [19]. The pressure drop because of the abrupt contraction and expansion was less than $2 \%$ of the total pressure drop. The vapor quality at the inlet of the test section is calculated as Equation (6).

$$
\begin{gathered}
h_{o}=h_{\text {in }}+\left(\frac{Q}{G}\right) \\
x=\frac{h_{o}-h^{\prime}}{h^{\prime \prime}-h^{\prime}}
\end{gathered}
$$

where $h_{0}$ and $h_{i n}$ are the outlet and inlet enthalpies of refrigerant. The inlet enthalpy of refrigerant just before the first preheater is estimated with refrigerant's bulk temperature and pressure. $Q$ is the amount of heat which is supplied by the electricity into the preheaters in direct heating method. $G$ is the mass flux of refrigerant. $h^{\prime}$ and $h^{\prime \prime}$ are the saturated liquid and vapor enthalpies, respectively. 
The vapor quality $x$ does not change enough along the test tube because no further heat is added to the refrigerant flowing in the test section.

The uncertainty of the condensation heat transfer coefficient and adiabatic pressure drop were calculated following the method by JCGM 100 [20]. The uncertainty analysis of the condensation heat transfer coefficient and frictional pressure drop can be carried out based on the basic equation of condensation heat transfer and frictional pressure drop as mentioned in Equations (1) and (3), respectively.

$$
\begin{gathered}
U(\alpha)=\sqrt{\left(\frac{\partial \alpha}{\partial q}\right)^{2} u^{2}(q)+\left(\frac{\partial \alpha}{\partial \Delta T}\right)^{2} u^{2}(\Delta T)} \\
U\left(\Delta P_{F}\right)=\sqrt{\left(\frac{\partial \Delta P_{F}}{\partial \Delta P_{T}}\right)^{2} u^{2}\left(\Delta P_{T}\right)+\left(\frac{\partial \Delta P_{F}}{\partial \Delta P_{c}}\right)^{2} u^{2}\left(\Delta P_{c}\right)+\left(\frac{\partial \Delta P_{F}}{\partial \Delta P_{e}}\right)^{2} u^{2}\left(\Delta P_{e}\right)}
\end{gathered}
$$

The uncertainties of the condensation heat transfer coefficient ranges from $6.1 \%$ to $20.5 \%$ and frictional pressure drop maximum uncertainty is $16.4 \%$. The heat balance of the all test run were within $\pm 10 \%$, which was calculated as Equation (10).

$$
H B=\frac{Q_{R}}{Q_{c}}
$$

The experiment repeatability was examined by repeated experiment at the same experimental conditions. Figure 4 shows the comparisons of the heat transfer coefficients and pressure drops obtained in two days in microfin tube. The mean deviations of the heat transfer coefficients and pressure drops were within about $8 \%$ and $9 \%$, respectively, showing good experiment repeatability.

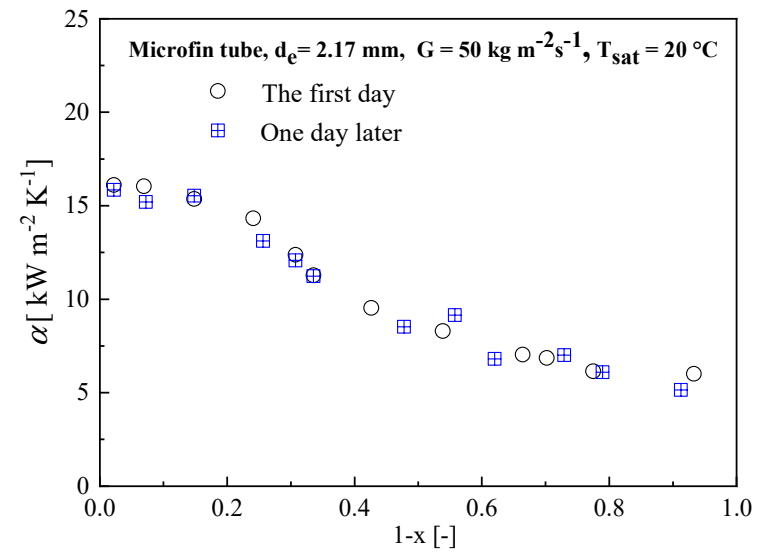

(a)

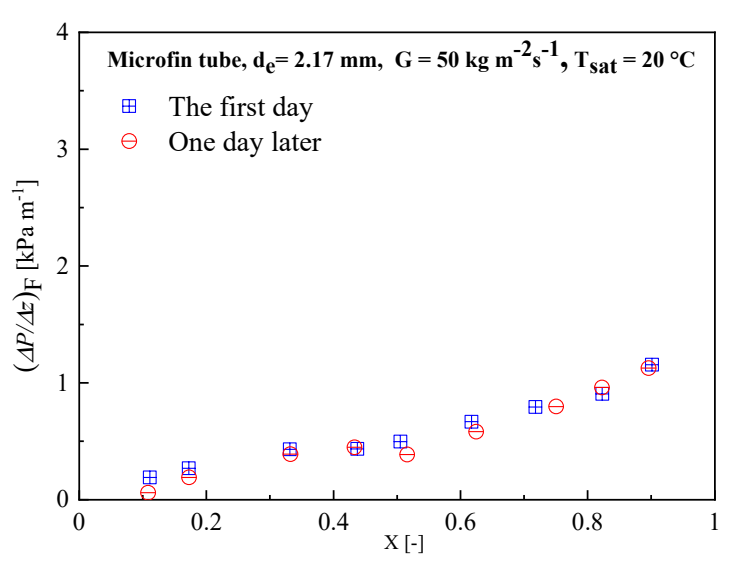

(b)

Figure 4. Repeatability of experiment: (a) heat transfer; and (b) pressure drop.

\section{Experimental Results and Discussion}

\subsection{Frictional Pressure Drop Results and Discussion}

The adiabatic pressure drop of R134a at saturation temperatures of 20 and $30^{\circ} \mathrm{C}$, mass fluxes ranging from 50 to $200 \mathrm{~kg} \mathrm{~m}^{-2} \mathrm{~s}^{-1}$ and vapor qualities from 0 to 1 were investigated. The effects of mass flux, vapor quality, saturation temperature and tube diameter of the frictional pressure drop were analyzed.

Figure $5 \mathrm{a}, \mathrm{b}$ shows the effects of mass flux and vapor quality on the frictional pressure drop, in smooth and microfin tubes for mass fluxes of 50,75 and $100 \mathrm{~kg} \mathrm{~m}^{-2} \mathrm{~s}^{-1}$ at a saturation temperature of $20^{\circ} \mathrm{C}$. As shown in Figure $5 \mathrm{a}, \mathrm{b}$, the frictional pressure drop increased as the mass flux increased. For a given mass flux, the pressure drop increased slightly at the low vapor quality $(x<0.3)$ region for both tubes. However, the rate of pressure drop increase was not same for the two tubes with the same experimental conditions: when mass flux increased from 50 to $100 \mathrm{~kg} \mathrm{~m}^{-2} \mathrm{~s}^{-1}$ for smooth tube, 
pressure drop increased about 2.3-4.5 times, while, for microfin tube, pressure drop increased about 2.4-6 times. The frictional pressure drop of microfin tube was approximately 1.5 times higher than that of smooth tube at $G=50 \mathrm{~kg} \mathrm{~m}^{-2} \mathrm{~s}^{-1}$. Therefore, the frictional pressure drop increased with fin due to the flow loss increase and turbulence generated by the fins. The range of pressure drop penalty factor was 1.01-2.11.

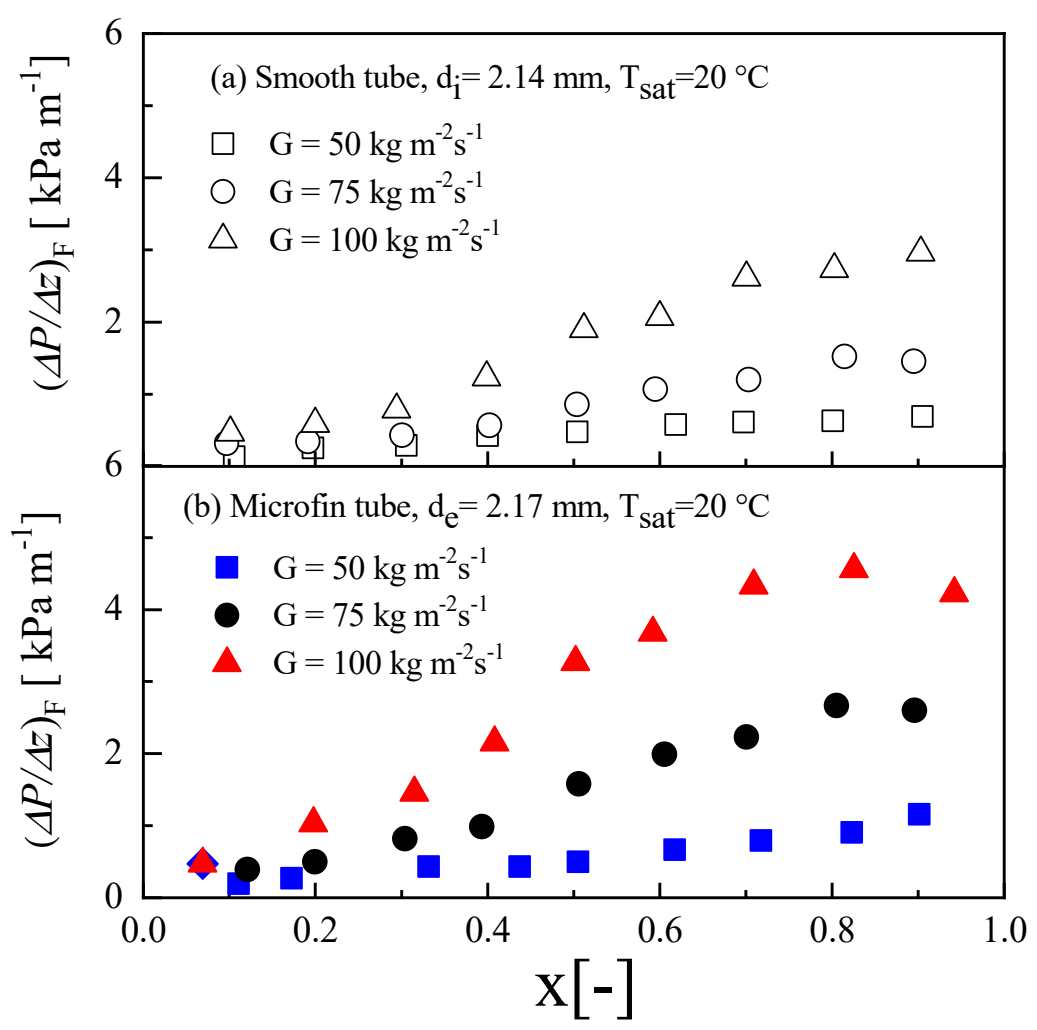

Figure 5. Effects of mass flux and vapor quality on frictional pressure drop: (a) smooth tube; and (b) microfin tube.

Figure 6 shows the effect of the saturation temperature on the frictional pressure drop at saturation temperatures of and $30{ }^{\circ} \mathrm{C}$ for mass fluxes of 100 and $200 \mathrm{~kg} \mathrm{~m}^{-2} \mathrm{~s}^{-1}$. According to the experimental results, when saturation temperature increased, the pressure drop decreased significantly because the saturation temperature changed the refrigerant properties, such as viscosity and density. Table 2 shows that, at $20{ }^{\circ} \mathrm{C}$, the liquid/gas density $\left(\rho_{l} / \rho_{v}\right)$ and viscosity $\left(\mu_{l} / \mu_{v}\right)$ ratio are 44.34 and 18.09 , respectively, while, at $30^{\circ} \mathrm{C}$, they are 31.79 and 15.41 , respectively. Similar experimental results were also observed by Rahman et al. [9] and Revellin and Thome [21].

Experimental data were collected for R134a with different diameter test tubes. Figure 7 shows the frictional pressure drop of R134a in microfin tube of $2.17 \mathrm{~mm}$ (this work), $2.68 \mathrm{~mm}$ [22] and $3.18 \mathrm{~mm}$ [8] at the mass flux and saturation temperature of $50 \mathrm{~kg} \mathrm{~m}^{-2} \mathrm{~s}^{-1}$ and $20^{\circ} \mathrm{C}$, respectively. The results for different tubes show that the frictional pressure drop of microfin tube $\left(d_{e}=3.18 \mathrm{~mm}\right)$ was lower than that of other microfin tubes. The second lowest was that of microfin tube $\left(d_{e}=2.68 \mathrm{~mm}\right)$, and the highest was that of microfin tube $\left(d_{e}=2.17 \mathrm{~mm}\right)$. The frictional pressure drop of $d_{e}=2.17 \mathrm{~mm}$ tube was on average approximately 1.2 times higher than that of the $d_{e}=3.18 \mathrm{~mm}$ tube. Thus, decreasing the tube diameter could increase the pressure drop. Similar experimental trends were also observed by Yan and Lin [23] and Cavalini et al. [24]. 


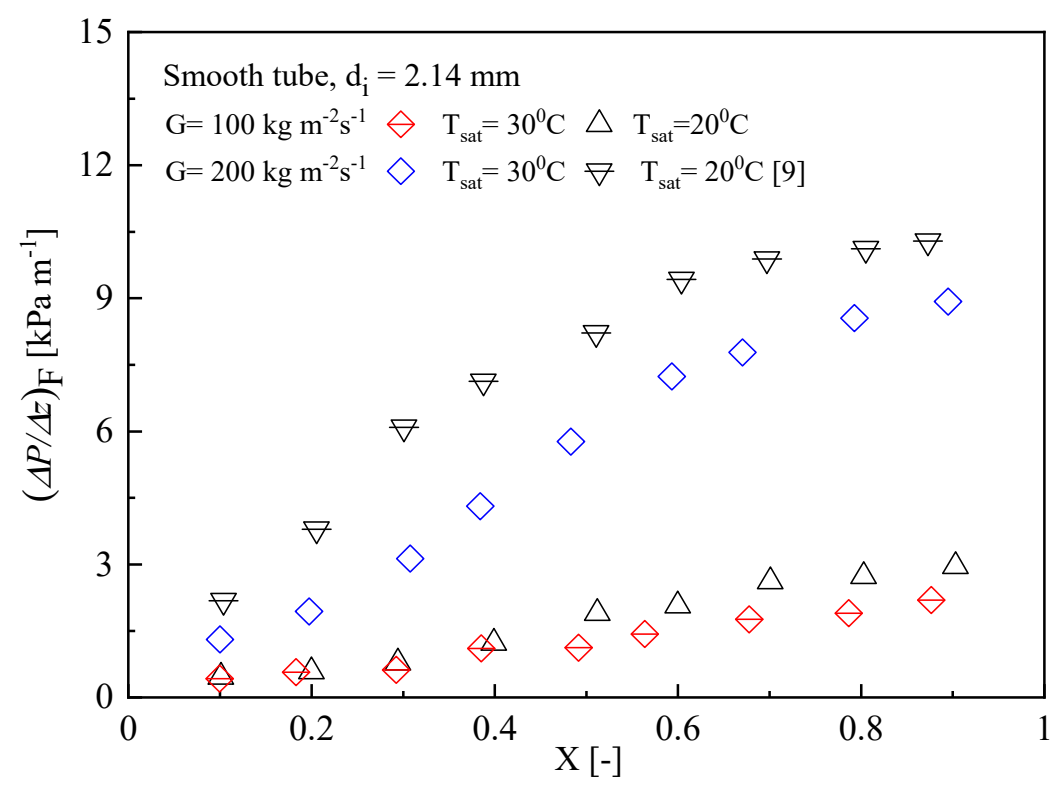

Figure 6. Effect of saturation temperature on frictional pressure drop.

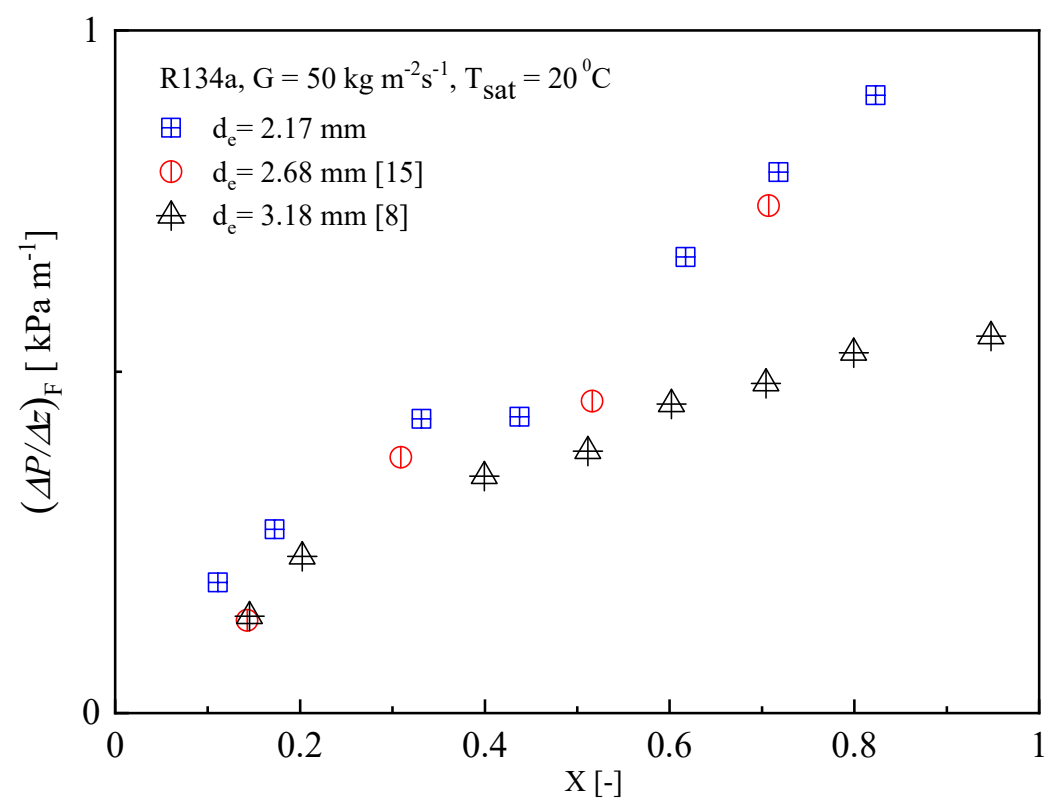

Figure 7. Effect of tube diameter on frictional pressure drop.

Comparison with the Pressure Drop Correlations

To validate the experimental procedure, the experimental frictional pressure drop data of the microfin and smooth tube were compared with the four pressure drop correlations proposed by Miyara et al. [2], Muller and Heck [25], Haraguchi et al. [26] and Olivier et al. [27], as shown in Figure 8. The compared frictional pressure drop correlations are listed in Table 3. The average deviation (AD) and mean deviation (MD) are listed in Table 4 and calculated by Equations (11) and (12), respectively. All correlations were well predicted for smooth tube data, but the microfin tube data were not predicted well.

$$
\begin{aligned}
& A D=\frac{1}{n} \sum_{i=1}^{n}\left(\frac{\Delta P_{F, \text { Pre }}-\Delta P_{F, \text { Exp }}}{\Delta P_{F, \text { Exp }}}\right) \times 100 \\
& M D=\frac{1}{n} \sum_{i=1}^{n}\left|\frac{\Delta P_{F, \text { Pre }}-\Delta P_{F, \text { Exp }}}{\Delta P_{F, \text { Exp }}}\right| \times 100
\end{aligned}
$$


Table 3. Pressure drop correlations.

\begin{tabular}{|c|c|c|}
\hline Author(s) & Correlation & Experimental Condition \\
\hline Miyara et al. [2] & $\begin{array}{c}\left(\frac{\Delta P}{\Delta z}\right)_{F}=\phi_{v}^{2}\left(\frac{\Delta P}{\Delta z}\right)_{v^{\prime}}\left(\frac{\Delta P}{\Delta z}\right)_{v}=\frac{0.092 G^{2} x^{2}}{d_{h} \rho_{v}\left(G x d_{h} / \mu_{v}\right.} \\
\phi_{v}=1.1+1.3 X_{t t}^{0.35}\left[\frac{G}{\left\{g d_{h} \rho_{v}\left(\rho_{l}-\rho_{v}\right)\right\}^{0.5}}\right]^{0.35}\end{array}$ & $\begin{array}{l}d_{o}=7 \mathrm{~mm}, \text { smooth, helical and } \\
\text { herringbone microfin tube. } \\
\text { Fluid: R410A, R22 } \\
\text { G: } 100-400 \mathrm{~kg} \mathrm{~m}^{-2} \mathrm{~s}^{-1} .\end{array}$ \\
\hline Muller and Heck [25] & $\begin{array}{c}\left(\frac{\Delta P}{\Delta z}\right)_{F}=E(1-x)^{1 / 3}+\left(\frac{\Delta P}{\Delta z}\right)_{P_{0}} x^{3} \\
E=\left(\frac{\Delta P}{\Delta z}\right)_{l o}+2\left[\left(\frac{\Delta P}{\Delta z}\right)_{v o}-\left(\frac{\Delta P}{\Delta z}\right)_{l o}\right] x\end{array}$ & $\begin{array}{c}d=4-392 \mathrm{~mm} \\
\text { Fluid: air-water, air-oil, } \\
\text { hydrocarbon, R11, R12, R22 } \\
\text { G: } 50-2490 \mathrm{~kg} \mathrm{~m}^{-2} \mathrm{~s}^{-1}\end{array}$ \\
\hline Haraguchi et al. [26] & $\begin{array}{c}\left(\frac{\Delta P}{\Delta z}\right)_{F}=\phi_{v}^{2}\left(\frac{\Delta P}{\Delta z}\right)_{v} \\
\left(\frac{\Delta P}{\Delta z}\right)_{v}=\frac{0.092 G^{2} x^{2}}{\rho_{v} d_{i}\left(G x d_{i} / \mu_{v}\right)^{0.2}} \\
\phi_{v}=1+0.5\left[\frac{G}{\left\{g d_{h} \rho_{v}\left(\rho_{l}-\rho_{v}\right)\right\}^{0.5}}\right]^{0.75} X_{t t}^{0.35}\end{array}$ & $\begin{array}{l}d_{i}=8.4 \mathrm{~mm}, \text { smooth tube. } \\
\text { Fluid: R134a, R123, R22 } \\
\text { G: } 99.8-402 \mathrm{~kg} \mathrm{~m}^{-2} \mathrm{~s}^{-1} \text {. }\end{array}$ \\
\hline Olivier et al. [27] & $\begin{array}{c}\left(\frac{\Delta P}{\Delta z}\right)_{F}=\phi_{l}^{2}\left(\frac{\Delta P}{\Delta z}\right)_{l o^{\prime}}\left(\frac{\Delta P}{\Delta z}\right)_{l 0}=\frac{2 f_{l o}[G(1-x)]^{2}}{d_{h} \rho_{l}} \\
\phi_{l}^{2}=1.376+\frac{7.242}{X_{t t}^{1.655}} \\
f_{l o}=0.046 R e_{l}^{-0.2}\left(\frac{d_{h}}{d_{e}}\right)\left(1-\frac{e n t}{\pi d_{h}^{2} \cos \beta}\right)^{0.5}(\sec \beta)^{0.75}\end{array}$ & $\begin{array}{c}d_{o}=9.51-9.55 \mathrm{~mm}, \\
\text { circular smooth, helical and } \\
\text { herringbone tube. } \\
\text { Fluid: R22, R407C, R134a } \\
\text { G: } 400-800 \mathrm{~kg} \mathrm{~m}^{-2} \mathrm{~s}^{-1} \text {. }\end{array}$ \\
\hline
\end{tabular}

Table 4. Deviations of frictional pressure drop. AD: average deviation; MD: mean deviation.

\begin{tabular}{ccccccc}
\hline \multirow{2}{*}{ Correlation } & \multicolumn{2}{c}{ Smooth Tube } & \multicolumn{2}{c}{ Microfin Tube } & \multicolumn{2}{c}{ All Data } \\
\cline { 2 - 7 } & AD (\%) & MD (\%) & AD (\%) & MD (\%) & AD (\%) & MD (\%) \\
\hline Miyara et al. [2] & -26.29 & 26.33 & -32.83 & 44.79 & -30.88 & 35.24 \\
Muller and Heck [18] & 11.64 & 22.93 & 7.50 & 40.88 & 7.05 & 30.03 \\
Haraguchi et al. [19] & 5.98 & 27.33 & -7.76 & 36.80 & 0.48 & 31.06 \\
Olivier et al. [20] & -26.72 & 33.29 & -41.95 & 46.75 & -34.11 & 40.89 \\
\hline
\end{tabular}

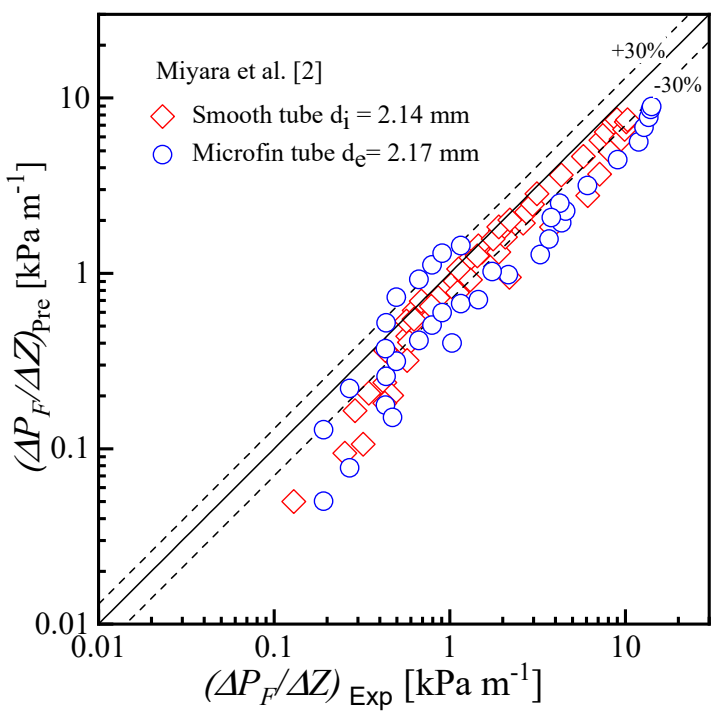

(a)

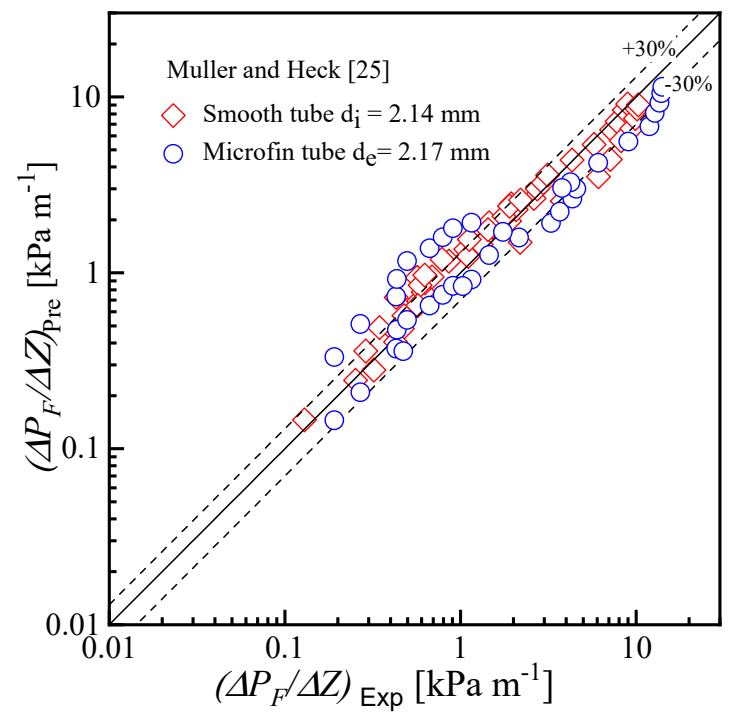

(b)

Figure 8. Cont. 


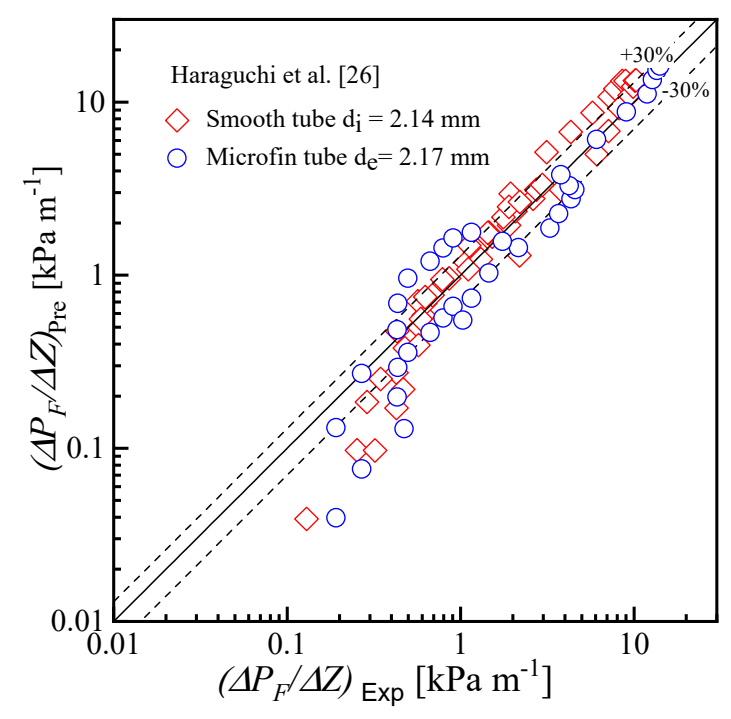

(c)

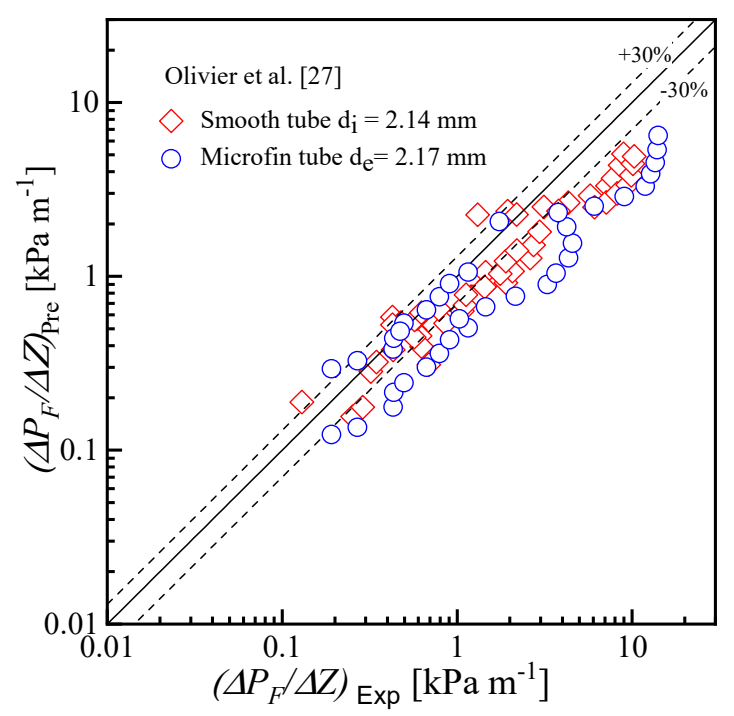

(d)

Figure 8. Comparison between the experimental and predicted frictional pressure drop using correlations by: (a) Miyara et al. [2]; (b) Muller and Heck [25]; (c) Haraguchi et al. [26]; and (d) Olivier et al. [27].

\subsection{Condensation Heat Transfer Coefficient Results and Discussion}

The condensation heat transfer coefficient of R134a at saturation temperatures of 20,25 and $30{ }^{\circ} \mathrm{C}$, mass fluxes ranging from 50 to $300 \mathrm{~kg} \mathrm{~m}^{-2} \mathrm{~s}^{-1}$ and vapor qualities from 0 to 1 were investigated. The effects of mass flux, vapor quality, saturation temperature and tube diameter on condensation heat transfer were analyzed. It was expected that the refrigerant's flow pattern would influence the mechanism of heat transfer during condensation process. Therefore, to categorize the condensation flow pattern inside the test tube, the present experimental data were predicted by two widely used flow pattern maps proposed by Scott [28] and Tandon et al. [29].

Figure 9 shows the experimental data plotted on the Scott [28] flow pattern map. In this flow pattern map, at a low mass flux of $50 \mathrm{~kg} \mathrm{~m}^{-2} \mathrm{~s}^{-1}$ for both tubes, wavy flow occurred in the entire range of quality. At mass fluxes of $100-300 \mathrm{~kg} \mathrm{~m}^{-2} \mathrm{~s}^{-1}$, many flow regimes occurred as the quality changed, and maximum of the data fall in annular flow and annular wavy regime. Moreover, few data obtained at the low vapor quality $(x<0.3)$ points fall into the slug and plug flow region. In the Tandon flow pattern map shown in Figure 10, most of the experimental data fall in the annular and semi-annular flow region, although very few data obtained at the low vapor quality $(x<0.2)$ fall in the slug flow region.

Figure 11 shows the effect of mass flux and vapor quality on condensation heat transfer coefficient by varying three mass fluxes. The figure also shows the heat transfer coefficient comparison of smooth and microfin tubes. For both tubes, the heat transfer coefficient increased significantly with an increase in mass flux, especially when the mass flux was larger than $50 \mathrm{~kg} \mathrm{~m}^{-2} \mathrm{~s}^{-1}$. At mass flux $300 \mathrm{~kg} \mathrm{~m}^{-2} \mathrm{~s}^{-1}$, the heat transfer coefficient was higher than at the two other mass fluxes because, at this mass flux, the data fall in annular flow region (shear dominated flow region), as shown in Figures 9 and 10. Moreover, in shear dominated flow regime, the local heat transfer was primarily affected by the mass flux and vapor quality [30]. However, the heat transfer coefficient was higher at the beginning of condensation for all mass fluxes and decreased as vapor shear stress decreased. A comparison of the results, for microfin and smooth tube, shows that the heat transfer coefficient of microfin tube was higher than that of smooth tube, for all mass flux conditions because the microfin provides additional heat transfer area and thin condensate film. The heat transfer coefficient of the microfin tube was about 2-5 times higher than that of the smooth tube at $100 \mathrm{~kg} \mathrm{~m}^{-2} \mathrm{~s}^{-1}$. 


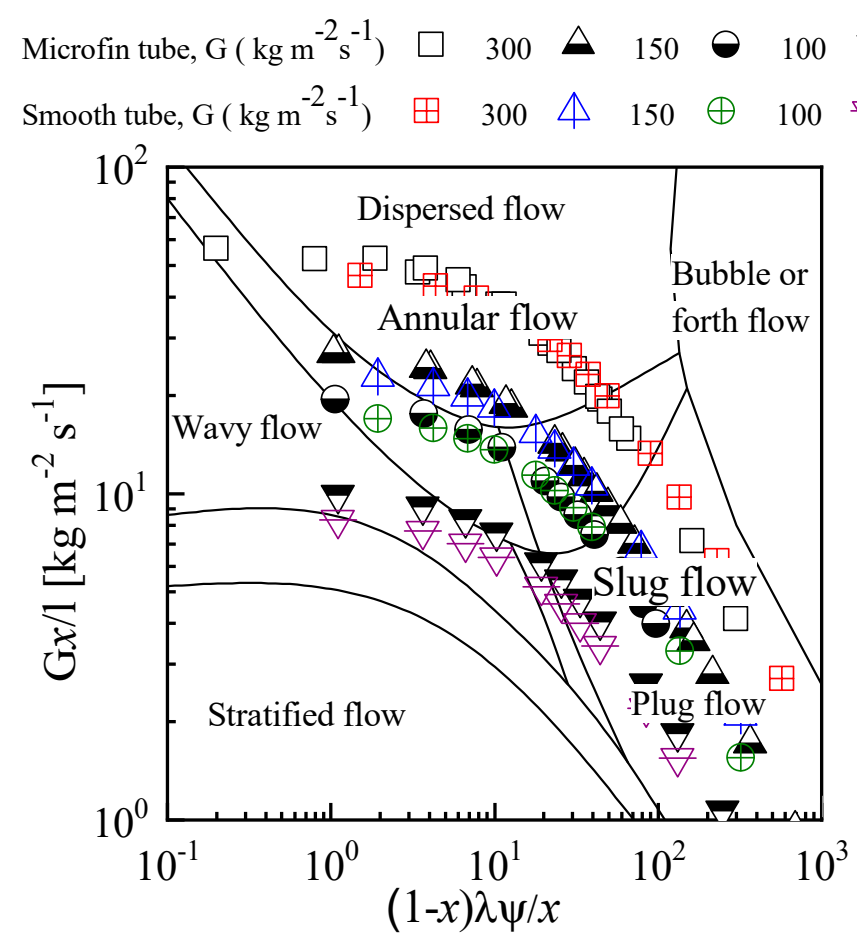

Figure 9. Flow pattern prediction by Scott flow pattern map [28].

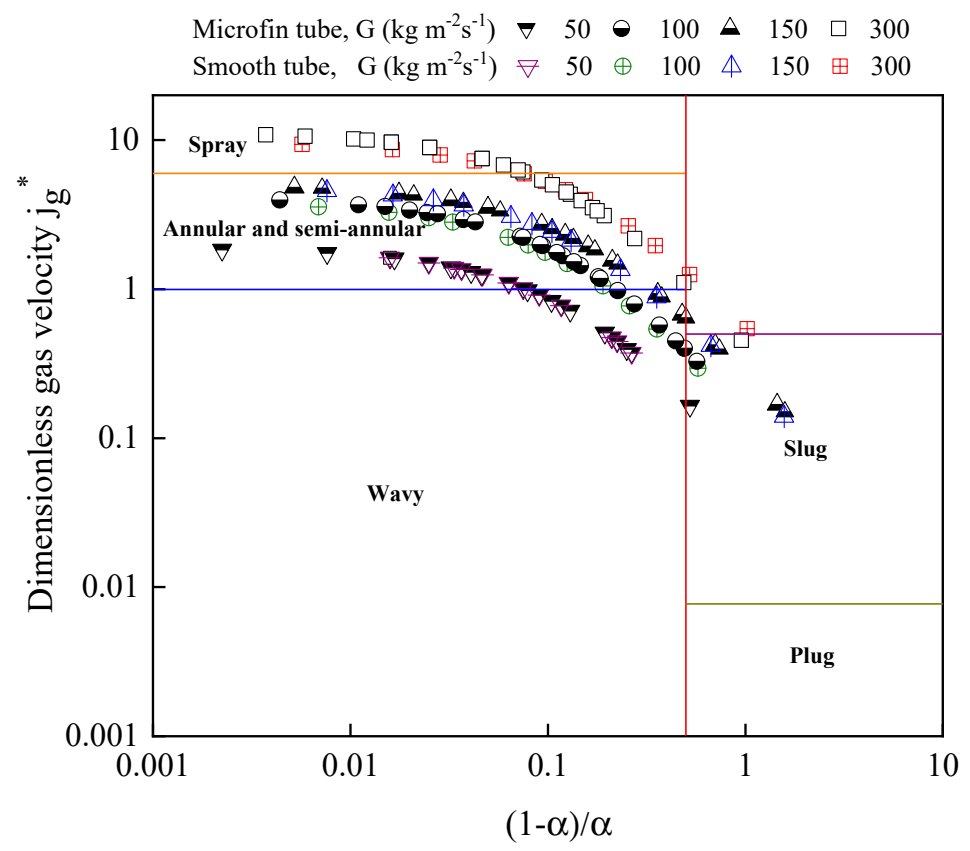

Figure 10. Flow pattern prediction by Tandon flow pattern map [29]. 


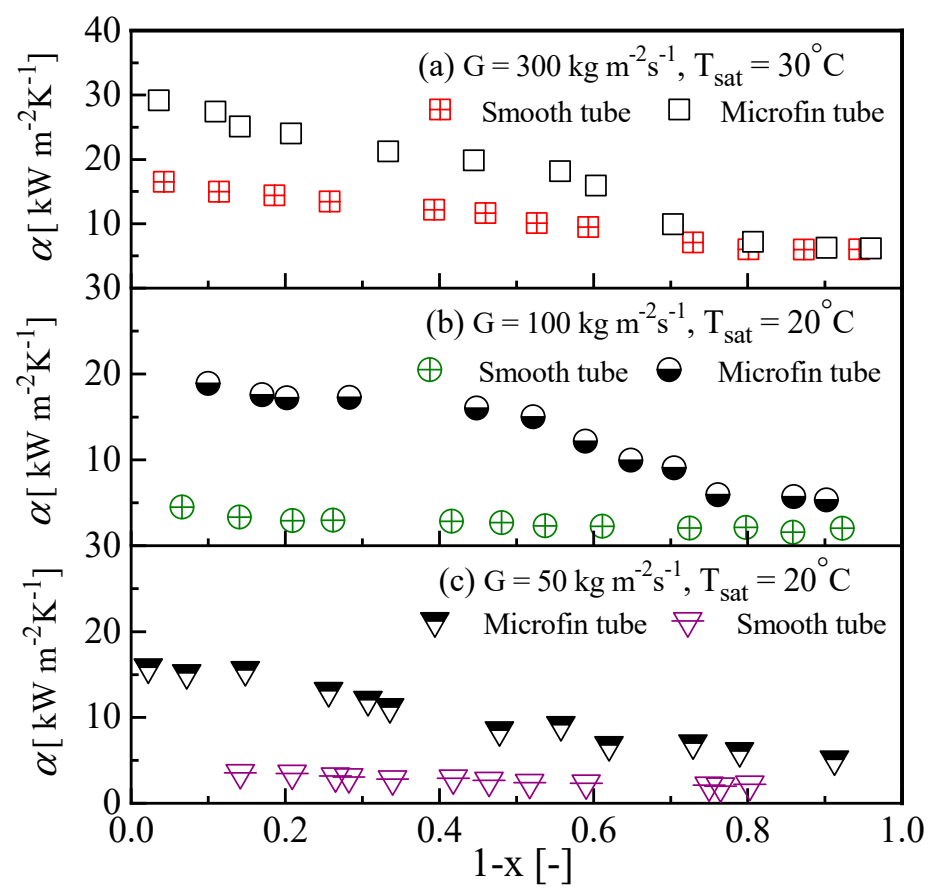

Figure 11. Effect of mass flux and vapor quality on condensation heat transfer coefficient at: (a) $G=300 \mathrm{~kg} \mathrm{~m}^{-2} \mathrm{~s}^{-1}$; (b) $G=100 \mathrm{~kg} \mathrm{~m}^{-2} \mathrm{~s}^{-1}$; and (c) $G=50 \mathrm{~kg} \mathrm{~m}^{-2} \mathrm{~s}^{-1}$.

Saturation temperature has an effect on condensation heat transfer coefficient. Experimental studies were conducted by changing the saturation temperature at a fixed mass flux of $100 \mathrm{~kg} \mathrm{~m}^{-2} \mathrm{~s}^{-1}$. Figure 12a shows the effect of saturation temperature on the heat transfer coefficient at saturation temperatures of 20 and $30^{\circ} \mathrm{C}$ for the smooth tube. Figure $12 \mathrm{~b}$ shows the effect of saturation temperature on the heat transfer coefficient at saturation temperatures of 20 and $25^{\circ} \mathrm{C}$ for microfin tube. According to the experimental results, when saturation temperature increased, the heat transfer coefficient decreased. Basically, when saturation temperature increases, system pressure also increases, thus the vapor velocity decreases due to the increase in vapor density. Moreover, the saturation temperature changes the thermophysical properties of refrigerant, as shown in Table 2.

Figures 13 and 14 show the effect of tube diameter on condensation heat transfer coefficient. Experimental data were collected for R134a with different test tube diameters. Figure 13 shows heat transfer coefficient of R134a in one smooth $\left(d_{i}=2.14 \mathrm{~mm}\right)$ and two microfin $\left(d_{e}=2.17\right.$ and $\left.3.18 \mathrm{~mm}\right)$ tubes at mass flux and saturation temperature of $50 \mathrm{~kg} \mathrm{~m}^{-2} \mathrm{~s}^{-1}$ and $20^{\circ} \mathrm{C}$, respectively. In Figures 13 and 14, the decrease of tube diameter can help to increase the heat transfer coefficient and comparing the results for the two microfin tubes shows that the heat transfer coefficient of $d_{e}=3.18 \mathrm{~mm}$ tube was about 1.1-1.6 times lower than $d_{e}=2.17 \mathrm{~mm}$ tube. Actually, when the tube diameter decreased, the effect of shear stress and surface tension enhanced, resulting in the easy occurrence of annular flow regime. Similar experimental trends were also observed by Cavalini et al. [24] and Son and Lee [31], as shown in Figure 14. 


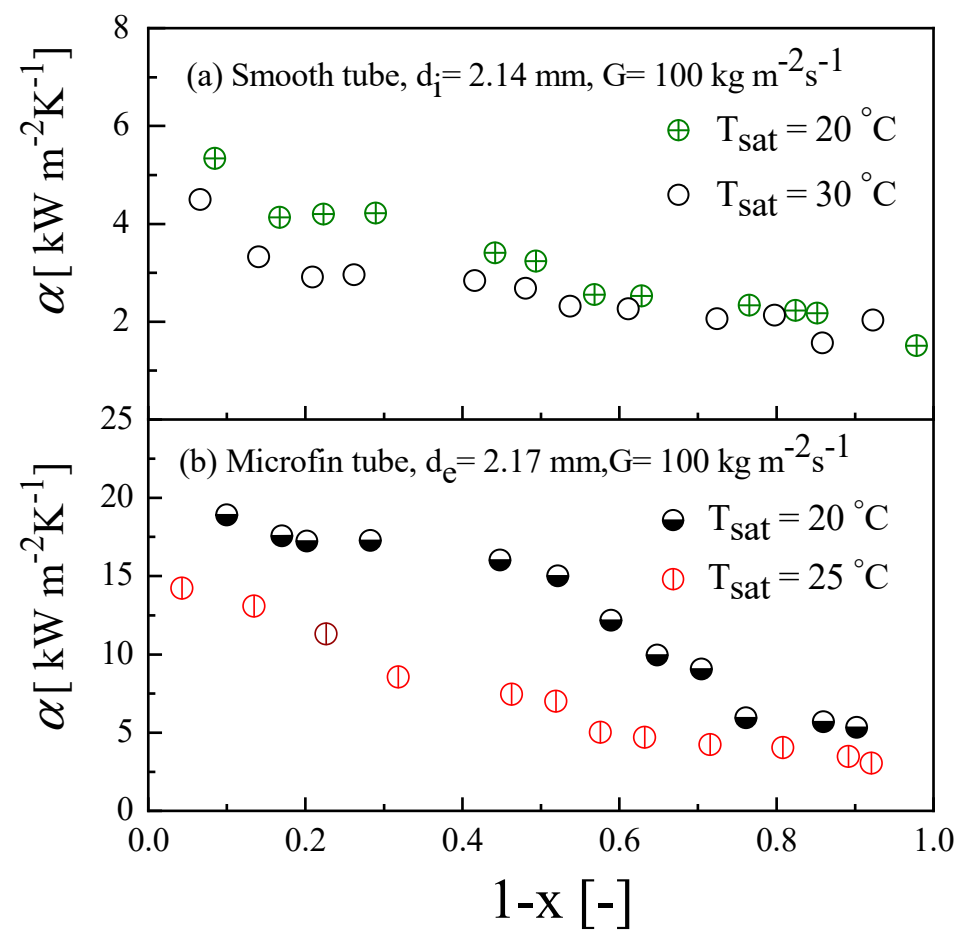

Figure 12. Effect of saturation temperature on condensation heat transfer coefficient: (a) smooth tube; and (b) microfin tube.

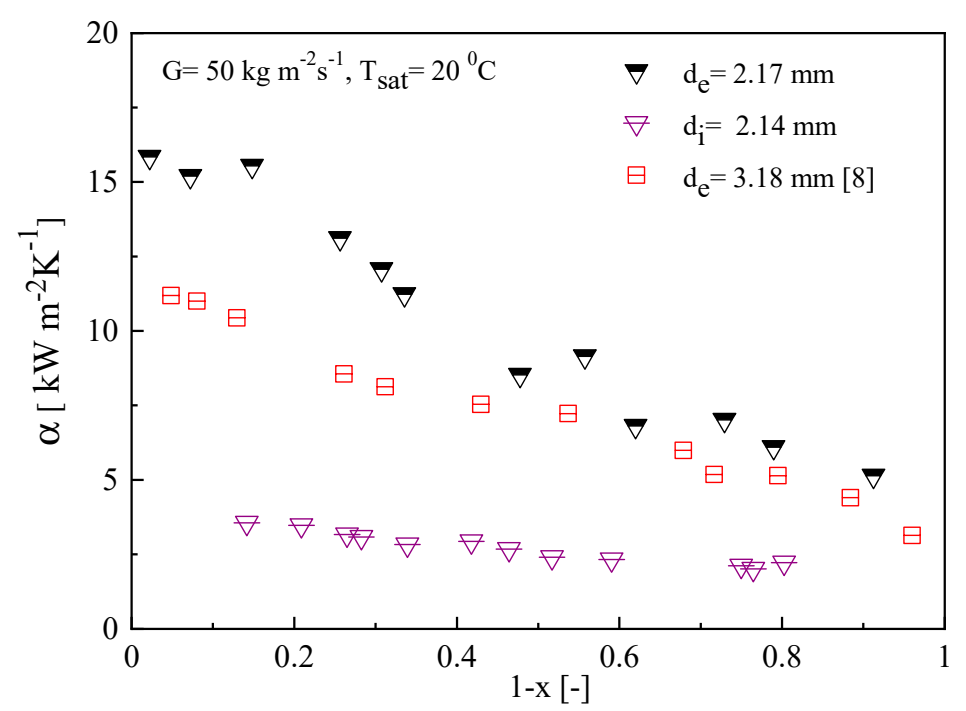

Figure 13. Effect of tube diameter on condensation heat transfer coefficient. 


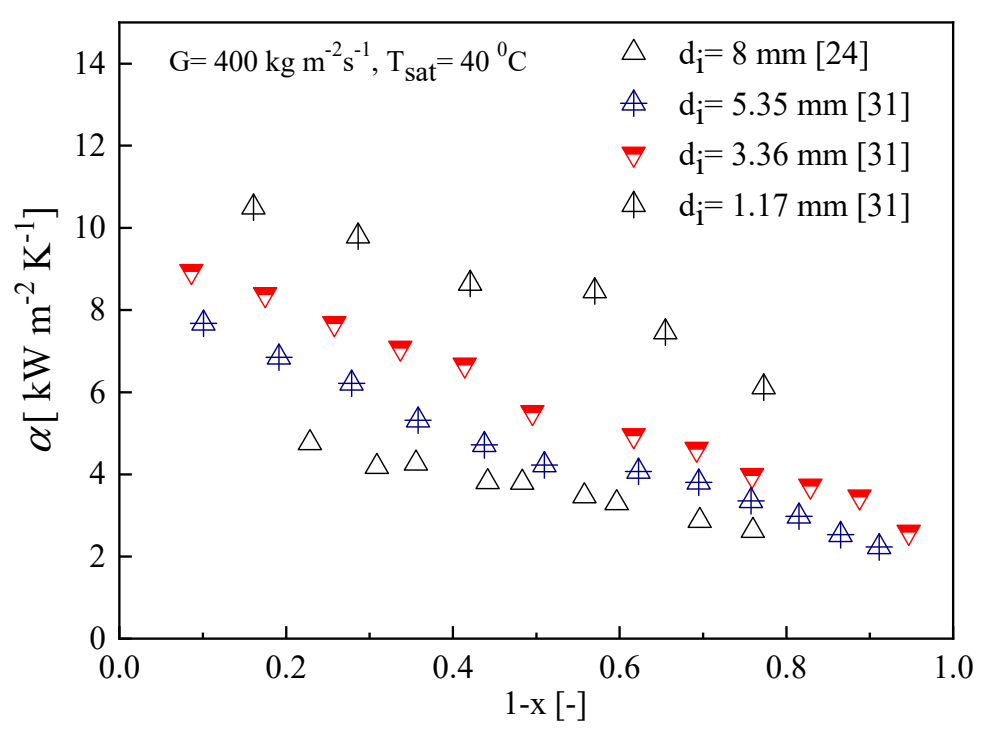

Figure 14. Average condensation heat transfer coefficient of different tube, inner diameter of $8 \mathrm{~mm}$ [24], $5.35 \mathrm{~mm}$ [31], $3.36 \mathrm{~mm}$ [31] and $1.17 \mathrm{~mm}$ [31] at mass flux $400 \mathrm{~kg} \mathrm{~m}^{-2} \mathrm{~s}^{-1}$.

\section{Comparison with the Condensation Heat Transfer Correlations}

To validate the experimental procedure, the experimental condensation heat transfer data of the microfin and smooth tube were compared with the four typical condensation heat transfer correlations proposed by Haraguchi et al. [32], Dobson and Chato [33], Koyama and Yonemoto [1] and Kedzierski and Goncalves [34], as shown in Figure 15. The compared condensation heat transfer correlations are listed in Table 5. The average deviation (AD) and mean deviation (MD) are listed in Table 6 and calculated by Equations (13) and (14), respectively.

$$
\begin{aligned}
& A D=\frac{1}{n} \sum_{i=1}^{n}\left(\frac{\alpha_{\text {Pre }}-\alpha_{\text {Exp }}}{\alpha_{\text {Exp }}}\right) \times 100 \\
& M D=\frac{1}{n} \sum_{i=1}^{n}\left|\frac{\alpha_{\text {Pre }}-\alpha_{\text {Exp }}}{\alpha_{\text {Exp }}}\right| \times 100
\end{aligned}
$$

\begin{tabular}{|c|c|c|}
\hline Author(s) & Correlation & Experimental Condition \\
\hline $\begin{array}{l}\text { Haraguchi et al. } \\
\text { [32] }\end{array}$ & $\begin{array}{c}h_{t p}=\frac{N u k_{l}}{d_{h}}, N u=\sqrt{N u_{F C}^{2}+N u_{G C}^{2}} \\
N u_{F C}=0.0152 R e_{l}^{0.77}\left(1+0.6 P r_{l}^{0.8}\right) \frac{\phi_{v}}{X_{t t}} \\
N u_{G C}=0.725 H(\xi)\left(\frac{G a_{l} P r_{l}}{P h}\right)^{0.25}\end{array}$ & $\begin{array}{l}d=8 \mathrm{~mm}, \text { smooth tube. } \\
\text { Fluid: R134a, R22, R123 } \\
\text { G: } 90-400 \mathrm{~kg} \mathrm{~m}^{-2} \mathrm{~s}^{-1}\end{array}$ \\
\hline $\begin{array}{l}\text { Dobson and } \\
\text { Chato [33] }\end{array}$ & $h_{t p}=0.023 \operatorname{Re}_{l}^{0.8} \operatorname{Pr}_{l}^{0.4}\left(1+\frac{2.22}{X_{t t}^{0.89}}\right) \frac{k_{l}}{d_{h}}$ & $\begin{array}{c}d=3.14-7.04 \mathrm{~mm} \text {, smooth tube. } \\
\text { Fluid: R134a, R12, R22, mixture } \\
\text { (R32/R125), G: 25-800 } \mathrm{kg} \mathrm{m}^{-2} \mathrm{~s}^{-1} \text {. }\end{array}$ \\
\hline $\begin{array}{l}\text { Koyama and } \\
\text { Yonemoto [1] }\end{array}$ & $\begin{array}{c}h_{t p}=\frac{N u k_{l}}{d_{i}}, N u=\sqrt{\left(N u_{F C}^{2}+N u_{N C}^{2}\right.} \\
N u_{F C}=2.12 \sqrt{f_{v}}\left(\frac{\rho_{l}}{\rho_{v}}\right)^{0.1}\left(\frac{x}{1-x}\right) \phi_{v} R e_{l}^{0.5} P r_{l}^{0.5} \\
N u_{N C}=1.98 \frac{H(\xi)}{\eta_{A}^{0.5} B 0^{0.1}}\left(\frac{G a P r_{l}}{P h_{l}}\right)^{0.25}\end{array}$ & $\begin{array}{l}d_{o}=7.52 \mathrm{~mm}, \text { microfin tube. } \\
\text { Fluid: R134a, R123, R22 } \\
\text { G: } 200-500 \mathrm{~kg} \mathrm{~m}^{-2} \mathrm{~s}^{-1}\end{array}$ \\
\hline $\begin{array}{l}\text { Kedzierski and } \\
\text { Goncalves [34] }\end{array}$ & $\begin{array}{c}h_{t p}=\frac{N u k_{l}}{d_{h}} \\
N u=4.94 \Omega R e_{l}^{0.235} \operatorname{Pr}_{l}^{0.308} S_{v}{ }^{2.708 x}\end{array}$ & $\begin{array}{c}d=3.14-7.04 \mathrm{~mm} \text {, microfin tube. } \\
\text { Fluid: } R 134 \mathrm{a}, \mathrm{R} 124, \mathrm{R} 32, \mathrm{R} 410 \mathrm{~A}, \\
\text { mixture (R32/R125) } \\
\text { G: } 57-552 \mathrm{~kg} \mathrm{~m}^{-2} \mathrm{~s}^{-1} .\end{array}$ \\
\hline
\end{tabular}

Table 5. Condensation heat transfer correlations. 
Table 6. Deviations of condensation heat transfer coefficient.

\begin{tabular}{ccccccc}
\hline \multirow{2}{*}{ Correlation } & \multicolumn{2}{c}{ Smooth Tube } & \multicolumn{2}{c}{ Microfin Tube } & \multicolumn{2}{c}{ All Data } \\
\cline { 2 - 7 } & AD (\%) & MD (\%) & AD (\%) & MD (\%) & AD (\%) & MD (\%) \\
\hline Haraguchi et al. [32] & 2.15 & 31.10 & -40.74 & 98.14 & -24.48 & 73.56 \\
Dobson and Chato [33] & -15.36 & 20.69 & -60.16 & 60.16 & -43.36 & 45.36 \\
Koyama and Yonemoto [1] & 99.57 & 99.68 & -12.47 & 35.87 & 27.97 & 59.19 \\
Kedzierski and Goncalves [34] & 75.48 & 77.62 & -34.42 & 40.10 & 6.06 & 53.92 \\
\hline
\end{tabular}

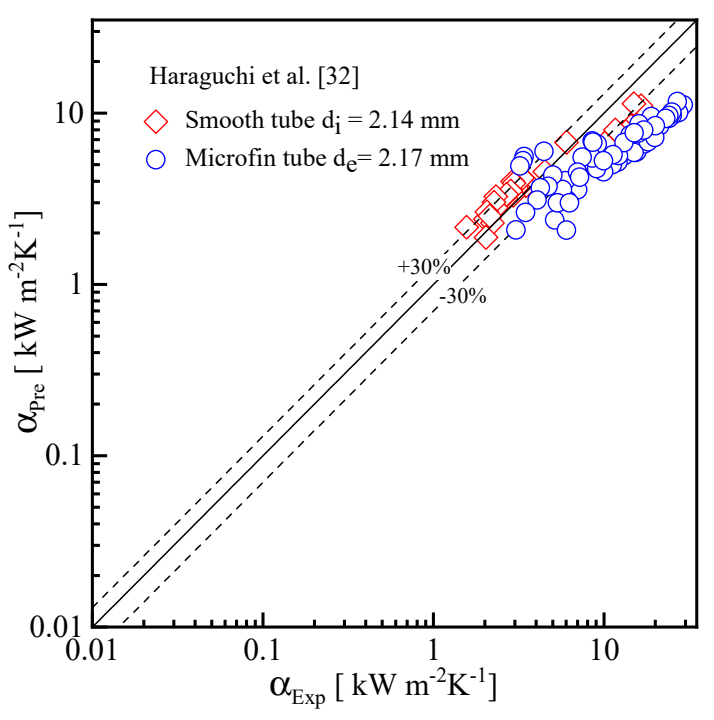

(a)

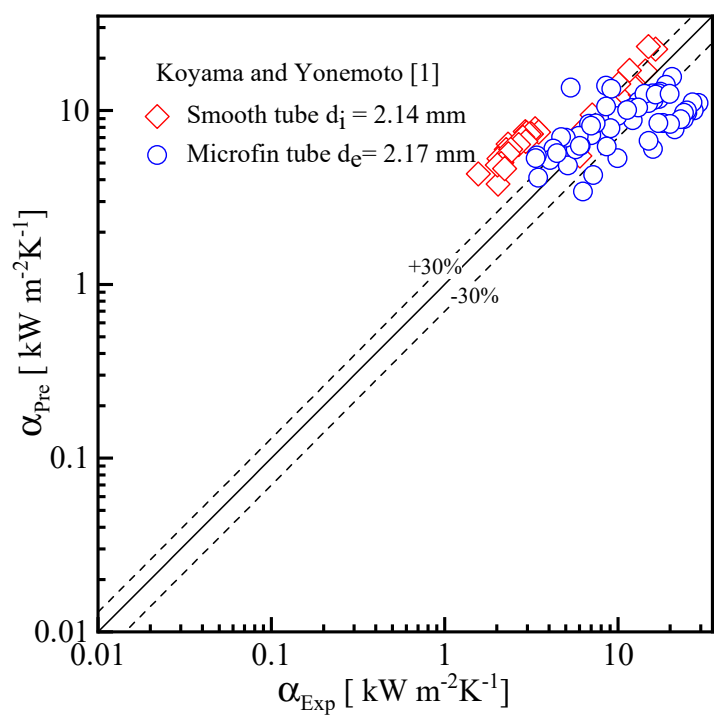

(c)

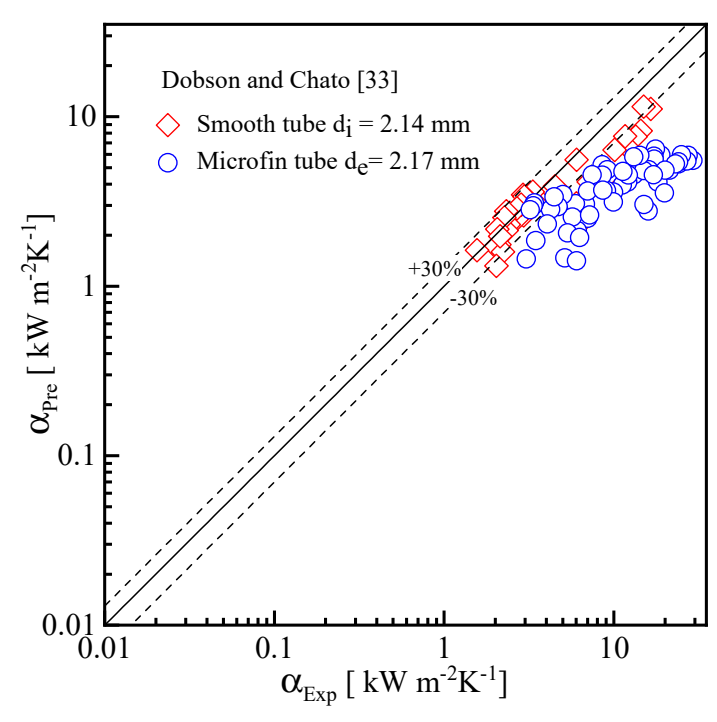

(b)

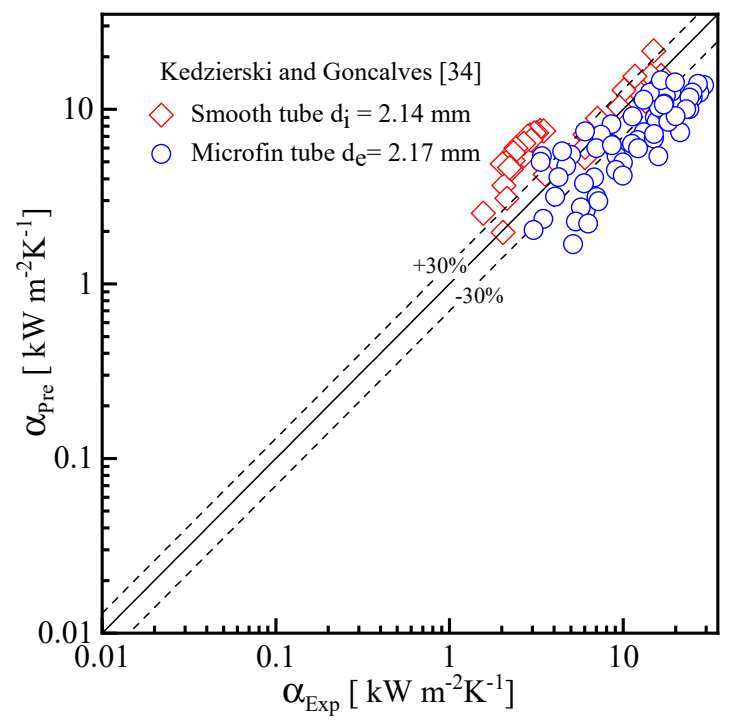

(d)

Figure 15. Comparison between the experimental and predicted condensation heat transfer coefficients using correlations: (a) Haraguchi et al. [32]; (b) Dobson and Chato [33]; (c) Koyama and Yonemoto [1]; and (d) Kedzierski and Goncalves [34].

\section{Conclusions}

Experiments were carried out to investigate the adiabatic pressure drop and condensation heat transfer coefficient of R134a in a horizontal smooth and microfin tube with outer diameter of $2.5 \mathrm{~mm}$. 
The experimental results for pressure drop, flow pattern and heat transfer were analyzed and compared with correlations. Some conclusions about this study are as follows.

The frictional pressure drop as well as condensation heat transfer coefficient increased with mass flux and vapor quality. The increase rate of pressure drop was higher in microfin tube compared to the smooth tube with the same experimental condition. The frictional pressure drop was higher in microfin tube for all mass fluxes and was about 1.5 times greater than that of smooth tube at mass flux $50 \mathrm{~kg} \mathrm{~m}^{-2} \mathrm{~s}^{-1}$. Pressure drop penalty factor range was 1.01-2.11.

Condensation flow patterns were predicted by two widely used flow pattern maps and annular, semi-annular, wavy, and slug and plug flow patterns were observed inside the tube. With the increase of mass flux, the zone of annular flow regime increased in the flow pattern map. Heat transfer coefficient was higher in microfin tube for all mass fluxes and was about 2-5 times greater than that of smooth tube at mass flux of $100 \mathrm{~kg} \mathrm{~m}^{-2} \mathrm{~s}^{-1}$. Decrease of tube diameter could increase heat transfer coefficient.

Four well-known pressure drop and condensation heat transfer correlations were used to predict the present experimental data. The pressure drop prediction correlations in ascending mean deviation order are: Muller and Heck, Haraguchi et al., Miyara et al., and Olivier et al. The heat transfer prediction correlations in ascending mean deviation order are: Dobson and Chato, Kedzierski and Goncalves, Koyama and Yonemoto, and Haraguchi et al.

Author Contributions: Investigation, M.K.B., and K.N.; Formal analysis, Data curation and Writing-original draft, M.K.B.; Supervision, K.K. and A.M.; and Project administration, A.M.

Funding: This research was funded by the Japan Copper Development Association.

Acknowledgments: The authors would like to thank the Japan Copper Development Association for their financial support.

Conflicts of Interest: The authors declare no conflict of interest.

\section{Nomenclature}

$A D$

Bo

$C_{c}$

$d$

G

$\mathrm{Ga}$

$h$

$h^{\prime \prime}$

$H B$

$k_{l}$

$L$ average deviation, dimensionless

Bond number, dimensionless

coefficient of contraction, dimensionless

diameter [m]

mass flux $\left[\mathrm{kg} \mathrm{m}^{-2} \mathrm{~s}^{-1}\right]$

Galileo number, dimensionless

heat transfer coefficient [ $\mathrm{W} \mathrm{m}^{-2} \mathrm{~K}^{-1}$ ]

saturated vapor enthalpy $\left[\mathrm{kJ} \mathrm{kg}^{-1}\right]$

heat balance, dimensionless

liquid thermal conductivity [ $\mathrm{W} \mathrm{m}^{-2} \mathrm{~K}^{-1}$ ]

heat transfer length $[\mathrm{m}]$

mean deviation, dimensionless

number of fin, dimensionless

Nusselt number, dimensionless

pressure $[\mathrm{Pa}]$

phase change number, dimensionless

Prandtl number, dimensionless

pressure drop [Pa]

heat exchange amount [W]

Reynolds number, dimensionless

temperature $\left[{ }^{\circ} \mathrm{C}\right]$

temperature difference between refrigerant and inner wall

specific volume $\left[\mathrm{m}^{3} \mathrm{~kg}^{-1}\right]$

quality, dimensionless

Lockhart-Martinelli parameter, dimensionless 


\section{Greek Symbol}

$\begin{array}{ll}\alpha & \text { heat transfer coefficient }\left[\mathrm{W} \mathrm{m}^{-2} \mathrm{~K}^{-1}\right] \\ \beta & \text { area ratio, dimensionless } \\ \xi & \text { void fraction, dimensionless } \\ \delta & \text { wall thickness [mm] } \\ \gamma & \left.\text { apex angle [ }{ }^{\circ}\right] \\ \theta & \text { helix angle }\left[^{\circ}\right] \\ \lambda_{c} & \text { thermal conductivity }\left[\mathrm{W} \mathrm{m}^{-2} \mathrm{~K}^{-1}\right] \\ \rho & \text { density }\left[\mathrm{kg} \mathrm{m}^{-3}\right] \\ \mu & \text { viscosity }\left[\mathrm{Pa} \mathrm{s}^{-1}\right] \\ \sigma & \text { surface tension }\left[\mathrm{N} \mathrm{m}{ }^{-1}\right] \\ \Phi & \text { two-phase multiplier, dimensionless }\end{array}$

\section{Subscripts}

$\begin{array}{ll}a & \text { adiabatic } \\ c & \text { coolant } \\ e & \text { equivalent } \\ \text { Exp } & \text { experimental } \\ F & \text { frictional } \\ F C & \text { forced convection } \\ G C & \text { gravity control convection condensation } \\ h & \text { hydraulic } \\ i & \text { inner } \\ l & \text { liquid } \\ l o & \text { liquid only } \\ N C & \text { natural convection } \\ o & \text { outer } \\ \text { Pre } & \text { prediction } \\ R & \text { refrigerant } \\ \text { Sat } & \text { saturation } \\ v & \text { vapor } \\ v o & \text { vapor only } \\ t p & \text { two-phase } \\ w i & \text { inner wall } \\ w o & \text { outer wall }\end{array}$

\section{References}

1. Koyama, S.; Yonemoto, R. Experimental study on condensation of pure refrigerants in horizontal microfin tube-proposal of correlations for heat transfer coefficient and frictional pressure drop. In Proceedings of the International Refrigeration and Air Conditioning Conference, West Lafayette, IN, USA, 17-20 July 2006; pp. 1-8.

2. Miyara, A.; Nonaka, K.; Taniguchi, M. Condensation heat transfer and flow pattern inside a herringbone-type micro-type tube. Int. J. Refrig. 2000, 23, 141-152. [CrossRef]

3. Kim, N.H. Condensation heat transfer and pressure drop of R-410A in a 7.0 mm O.D microfin tube at low mass fluxes. Heat Mass Transf. 2016, 52, 2833-2847. [CrossRef]

4. Kondou, C.; Mishima, F.; Liu, J.; Koyama, S. Condensation and evaporation of R134a, R1234ze(E) and $\mathrm{R} 1234 z e(Z)$ flow in horizontal microfin tubes at higher temperatures. In Proceedings of the International Refrigeration and Air Conditioning Conference, West Lafayette, IN, USA, 14-17 July 2014; pp. 1-8.

5. Wu, Z.; Sunden, B.; Wang, L.; Li, W. Convective condensation inside horizontal smooth and microfin tubes. J. Heat Transf. 2014, 136, 051504. [CrossRef]

6. Diani, A.; Cavallini, A.; Rossetto, L. R1234yf condensation inside a $3.4 \mathrm{~mm}$ ID horizontal microfin tube. Int. J. Refrig. 2017, 75, 178-189. [CrossRef] 
7. Hirose, M.; Ichinose, J.; Inoue, N. Development of the general correlation for condensation heat transfer and pressure drop inside horizontal $4 \mathrm{~mm}$ small-diameter smooth and microfin tubes. Int. J. Refrig. 2018, 90, 238-248. [CrossRef]

8. Bashar, M.K.; Nakamura, K.; Kariya, K.; Miyara, A. Condensation heat transfer and pressure drop characteristics inside small diameter microfin tubes. In Proceedings of the Japan Society of Refrigeration and Air Conditioning Annual Conference, Koriyama, Japan, 4-7 September 2018; pp. 1-6.

9. Rahman, M.M.; Kariya, K.; Miyara, A. Experimental investigation of condensation heat transfer and adiabatic pressure drop characteristics inside $2.13 \mathrm{~mm}$ ID microfin and smooth tube. Int. J. Air-Cond. Refrig. 2017, 25, 1750027. [CrossRef]

10. Zhuang, X.R.; Chen, G.F.; Guo, H.; Song, Q.L.; Tang, Q.X.; Yang, Z.Q.; Zou, X.; Gong, M.Q. Experimental investigation on flow condensation of zeotropic mixture of methane/ethane in a horizontal smooth tube. Int. J. Refrig. 2018, 85, 120-134. [CrossRef]

11. Fronk, B.M.; Garimella, S. Condensation of ammonia and high-temperature-glide ammonia/water zeotropic mixtures in minichannels-Part I: Measurements. Int. J. Heat Mass Transf. 2016, 101, 1343-1356. [CrossRef]

12. Dorao, C.A.; Fernandino, M. Simple and general correlation for heat transfer during flow condensation inside plain pipes. Int. J. Heat Mass Transf. 2018, 122, 290-305. [CrossRef]

13. Xiao, J.; Hrnjak, P. Heat transfer and pressure drop of condensation from superheated vapor to subcooled liquid. Int. J. Heat Mass Transf. 2016, 103, 1327-1334. [CrossRef]

14. Ghim, G.; Lee, J. Condensation heat transfer of low GWP ORC working fluids in a horizontal smooth tube. Int. J. Heat Mass Transf. 2017, 104, 718-728. [CrossRef]

15. Meyer, J.P.; Ewim, D.R.E. Heat transfer coefficients during the condensation of low mass fluxes in smooth horizontal tubes. Int. J. Multiph. Flow. 2018, 99, 485-499. [CrossRef]

16. Shah, M.M. Improved correlation for heat transfer during condensation in conventional and mini/micro channels. Int. J. Refrig. 2018. [CrossRef]

17. Lemmon, E.W.; Huber, M.L.; McLinden, M.O. Reference Fluid Thermodynamic and Transport Properties-REFPROP [9.1]; NIST Standard Reference Database; NIST: Gaithersburg, MD, USA, 2013.

18. Collier, J.G.; Thome, J.R. Convective Boiling and Condensation, 3rd ed.; Oxford University Press: Oxford, UK, 1994.

19. Smith, S.L. Void fractions in two-phase flow: A correlation based upon an equal velocity head model. Proc. Inst. Mech. Eng. 1969, 184, 647-664. [CrossRef]

20. JCGM 100. Evaluation of Measurement Data-Guide to the Expression of Uncertainty in Measurement; JCGM: Sèvres, France, 2008.

21. Revellin, R.; Thome, J.R. Adiabatic two-phase frictional pressure drops in microchannels. Exp. Therm. Fluid Sci. 2008, 31, 673-685. [CrossRef]

22. Ichinose, Y.; Kudo, Y.; Bashar, M.K.; Kariya, K.; Miyara, A. Boiling and condensation heat transfer and pressure drop of grooved small copper tube. In Proceedings of the Japan Society of Mechanical Engineering, Saga, Japan, 19-22 September 2017; pp. 13-14.

23. Yan, Y.Y.; Lin, T.F. Condensation heat transfer and pressure drop of refrigerant R-134a in a small pipe. Int. J. Heat Mass Transf. 1999, 42, 697-708. [CrossRef]

24. Cavallini, A.; Censi, G.; Del Col, D.; Doretti, L.; Longo, G.A.; Rossetto, L. Experimental investigation on condensation heat transfer and pressure drop of new HFC refrigerants (R134a, R125, R32, R410A, R236ea) in a horizontal smooth tube. Int. J. Refrig. 2001, 24, 73-87. [CrossRef]

25. Steinhagen, M.H.; Heck, K.A. Simple frictional pressure drop correlation for two-phase flow in pipes. Chem. Eng. Process. 1986, 20, 297-308. [CrossRef]

26. Haraguchi, H.; Koyama, S.; Fujii, T. Condensation of refrigerants HCFC 22, HFC 134a and HCFC 123 in a horizontal smooth tube (1st report, proposals of empirical expression for the local frictional pressure drop). JSME Int. J. 1994, 60, 2111-2116.

27. Olivier, J.A.; Liebenberg, L.; Kedzierski, M.A.; Meyer, J.P. Pressure drop during condensation inside horizontal smooth, helical microfin, and herringbone microfin tubes. J. Heat Transf. 2004, 126, 687-696. [CrossRef]

28. Scott, D.S. Properties of co-current gas-liquid flow. Adv. Chem. Eng. 1964, 4, 199-276.

29. Tandon, T.N.; Varma, H.K.; Gupta, G.P. A new flow regimes map for condensation inside horizontal tubes. Int. J. Heat Transf. 1982, 104, 763-768. [CrossRef] 
30. Wang, L.; Dang, C.; Hihara, E. Experimental study on condensation heat transfer and pressure drop of low GWP refrigerant HFO1234yf in a horizontal tube. Int. J. Refrig. 2012, 35, 1418-1429. [CrossRef]

31. Son, C.H.; Lee, H.S. Condensation heat transfer characteristics of R-22, R-134a and R-410A in small diameter tubes. Heat Mass Transf. 2009, 45, 1153-1166. [CrossRef]

32. Haraguchi, H.; Koyama, S.; Fujii, T. Condensation of refrigerants HCFC 22, HFC 134a and HCFC 123 in a horizontal smooth tube (2nd report, proposals of empirical expressions for the local heat transfer coefficient). JSME Int. J. 1994, 60, 245-252.

33. Dobson, M.K.; Chato, J.C. Condensation in smooth horizontal tubes. J. Heat Transf. 1998, 120, $192-213$. [CrossRef]

34. Kedzierski, M.A.; Goncalves, J.M. Horizontal convective condensation of alternative refrigerants within a microfin tube. J. Enhanced Heat Transf. 1999, 6, 161-178. [CrossRef]

(C) 2018 by the authors. Licensee MDPI, Basel, Switzerland. This article is an open access article distributed under the terms and conditions of the Creative Commons Attribution (CC BY) license (http://creativecommons.org/licenses/by/4.0/). 